\title{
Regulatory T-cell Subpopulations in Severe or Early-onset Preeclampsia
}

\author{
Roland Boij, Jenny Mjosberg, Judit Svensson Arvelund, Maria Hjorth, Göran Berg, Leif \\ Matthiesen, Maria Jenmalm and Jan Ernerudh
}

\section{Linköping University Post Print}

\section{Tweet}

N.B.: When citing this work, cite the original article.

Original Publication:

Roland Boij, Jenny Mjosberg, Judit Svensson Arvelund, Maria Hjorth, Göran Berg, Leif Matthiesen, Maria Jenmalm and Jan Ernerudh, Regulatory T-cell Subpopulations in Severe or Early-onset Preeclampsia, 2015, American Journal of Reproductive Immunology, (74), 4, 368378.

http://dx.doi.org/10.1111/aji.12410

Copyright: Wiley: 12 months

http://eu.wiley.com/WileyCDA/

Postprint available at: Linköping University Electronic Press

http://urn.kb.se/resolve?urn=urn:nbn:se:liu:diva-122528 


\section{Regulatory T cell Subpopulations in Severe or Early-onset Preeclampsia}

\section{AUTHORS}

Roland Boij*, M D, Department of Clinical and Experimental Medicine, Linköping University, Linköping, Sweden and Department of Obstetrics and Gynecology, County Hospital Ryhov, SE-551 85 Jönköping, Sweden

Jenny Mjösberg*, Ph D, Center for Infectious Medicine, Department of Medicine Huddinge, Karolinska Institutet, Stockholm, Sweden

Judit Svensson-Arvelund, Ph D student, Department of Clinical and Experimental Medicine, Linköping University, Linköping, Sweden

Maria Hjorth, Ph D, Department of Clinical Immunology and Transfusion Medicine, Linköping University, Linköping, Sweden.

Göran Berg, M D, Ph D, Department of Clinical and Experimental Medicine, Linköping University, Linköping, Sweden

Leif Matthiesen, M D, Ph D, Department of Clinical and Experimental Medicine, Linköping University, Linköping, Sweden and Department of Obstetrics and Gynecology, Helsingborg Hospital, Helsingborg Sweden

Maria C Jenmalm, Ph D, Department of Clinical and Experimental Medicine, Linköping University, Linköping, Sweden.

Jan Ernerudh, M D, Ph D, Department of Clinical Immunology and Transfusion Medicine and Department of Clinical and Experimental Medicine, Linköping University, Linköping, Sweden.

*Contributed equally

Corresponding author: Roland Boij, boijro@gmail.com

Short title: Regulatory T cell Subpopulations in Severe or Early-onset Preeclampsia

Key words: Early-onset preeclampsia, Preeclampsia, Regulatory T cells, Pregnancy 


\section{ABSTRACT}

\section{Problem}

A deficiency in regulatory $\mathrm{T}$ (Treg) cells causing reduced immune regulatory capacity has been proposed in preeclampsia.

\section{Objective}

Utilizing recent advances in flow cytometry phenotyping, we aimed to assess whether a deficiency of Treg subpopulations occurs in preeclampsia.

\section{Method of Study}

Six-color flow cytometry was used for Treg phenotyping in 18 preeclamptic women (1 early-onset, 1 severe and 16 both), 20 women with normal pregnancy and 20 non-pregnant controls.

\section{Results}

No differences were found in major Treg populations including $\mathrm{CD} 127^{\text {low }} \mathrm{CD} 25^{+} / \mathrm{CD} 127^{\text {ow }} \mathrm{FOXP} 3^{+}$, resting $\left(\mathrm{FOXP} 3{ }^{\mathrm{dim}} \mathrm{CD} 45 \mathrm{RA}^{+}\right)$and activated (FOXP3 ${ }^{\text {bright }} \mathrm{CD}^{2} 5 \mathrm{RA}^{-}$) Treg cells, whereas preeclamptic women showed increased CTLA$4^{+}$and $\mathrm{CCR} 4^{+}$proportions within resting/activated Treg populations. Corticosteroidtreatment prior to blood sampling $(n=10)$ affected the distribution of Treg populations.

\section{Conclusions}

Although we found no major alterations in circulating Treg frequencies, differences in $\mathrm{CTLA}-4^{+}$and CCR $4^{+}$frequencies suggest a migratory defect of Treg cells in preeclampsia. Corticosteroid treatment should be taken into account when evaluating Treg cells. 


\section{INTRODUCTION}

Preeclampsia and eclampsia are among the most frequent causes of maternal and fetal mortality and morbidity affecting 2-10\% of the pregnant population worldwide (1). There is still no generally accepted etiology of preeclampsia, but an increasing amount of data indicate involvement of the immune system, with a defective tolerance to the conceptus being an integral part of the pathogenesis, in particular in early-onset and severe preeclampsia (2). The end result is a state of exaggerated systemic inflammation (3-7) with activated circulating T cells (8-10) and increased production of interferon-gamma (IFN- $\gamma$ ) $(8,11,12)$. It is therefore reasonable to suspect that a defect in the regulation of $\mathrm{T}$ cells could be involved in the development of preeclampsia.

Regulatory T (Treg) cells represent one of the major immune regulators(13), suppressing many cell types including T cells (14) via mechanisms that are incompletely understood but involving cell-cell contact through for example CTLA-4 as well as secretion of soluble mediators like the cytokines interleukin 10 (IL-10), transforming growth factor $\beta$ (TGF- $\beta$ ) and IL-35 $(15,16)$. In humans, Treg cells are identified as CD4 ${ }^{+} \mathrm{T}$ helper cells expressing forkhead box P3 (FOXP3) (14) and high levels of the IL-2 receptor $\alpha$-chain, CD25 (14, 15). Early reports indicated that the circulating Treg pool was expanded in normal human

pregnancy (17-20). However, with increasing insights in the complexity of Treg markers in humans, subsequent studies did not report increased frequency in the circulation (21-25). Instead it seems that highly suppressive Treg cells are enriched in the decidua (23, 26-28). One mechanism for this enrichment is through abundant decidual CCL17 expression (29) and recruitment of CCR4 expressing Treg cells (28). 
In preeclampsia, reduced numbers of circulating Treg cells have been reported (for review see 30) although these findings were not confirmed in other studies (31-33). One reason for the inconsistency could be the selection of cases in a heterogeneous condition like preeclampsia. Since severe and early-onset preeclampsia with growth-retarded fetuses is associated with increased disease severity and placental pathology, this entity might represent a more homogeneous placental disease. Thus, research on this sub-group has been encouraged (34). Also, treatment with corticosteroids could influence Treg cell frequencies and phenotype (35), which is important in preeclampsia where corticosteroids are often administered at an early time point to enhance fetal lung maturation. The most prominent factor explaining inconsistent results is likely how Treg cells were defined. One major problem is that both CD25 and FOXP3, the key phenotypic markers, are expressed upon activation of conventional $\mathrm{CD} 4^{+} \mathrm{T}$ cells, which implies difficulties in enumeration of "true" Treg cells in diseases with systemic T cell activation such as preeclampsia.

Different flow cytometric strategies and markers have evolved to circumvent the inclusion of activated non-suppressive ("false positive") Treg cells; (1) lower CD4 expression on suppressive Treg cells than conventional CD4 cells (“CD4 dim”) (36); (2) low or no expression of the IL-7 alpha receptor subunit CD127 (37); (3) CD45RA to distinguish suppressive (“true”) resting Treg cells $\left(\mathrm{FOXP} 3{ }^{\mathrm{dim}} \mathrm{CD} 45 \mathrm{RA}{ }^{+}\right)$from non-suppressive, activated FOXP3 expressing T helper cells (FOXP3 $\left.{ }^{\mathrm{dim}} \mathrm{CD}^{4} 4 \mathrm{RA}^{-}\right)$(38). This strategy, which has not been used in studies of preeclampsia, not only excludes false positive (nonsuppressive $\mathrm{FOXP}^{+}$) cells, but also defines the balance between resting $\left(\mathrm{FOXP}^{\mathrm{dim}} \mathrm{CD} 45 \mathrm{RA}^{+}\right)$and activated (FOXP3 $\left.{ }^{\text {bright }} \mathrm{CD} 45 \mathrm{RA}^{-}\right)$Treg cells.

The aim of our study was to assess whether the frequency and phenotype of circulating Treg cells differs in women with preeclampsia compared with pregnant and non-pregnant controls when using a set of updated Treg and phenotype markers. Since early onset and 
severe preeclampsia is associated with significant morbidity and mortality and may constitute a homogeneous group, we focused our work around these patients, and we also paid special attention to effects of corticosteroid treatment.

\section{MATERIALS AND METHODS}

\section{Subjects}

Eighteen women with de novo proteinuria and hypertension appearing after gestational week 20 were included (Table 1). Inclusion criteria were either severe or early onset preeclampsia. Severe preeclampsia was defined as highest measured blood pressure $\geq$ $160 / 110 \mathrm{mmHg}$ and/or with signs of renal, hepatic or neurological impairment or thrombocytopenia (39), while early-onset preeclampsia was defined by onset at gestational age of less than 34 weeks $(40,41)$. Included patients had either severe $(n=1)$ or early-onset $(\mathrm{n}=1)$ preeclampsia or both $(\mathrm{n}=16)$. Women with diabetes, BMI $>35$, chronic hypertension, thrombophilia and twin pregnancies were excluded. The majority (72.2\%) of preeclampsia patients delivered small for gestational age babies as a sign of placental involvement in pathogenesis. Treatment with antenatal betamethasone to facilitate fetal lung maturity, consisting of two intramuscular injections of $12 \mathrm{mg}$ with an interval of 24 hours, was started prior to blood sampling in 10 out of 18 preeclamptic women. Blood sampling was done in close proximity to treatment, in most cases between the first and the second injection. Median time from first injection of betamethasone to blood sampling was 23.5 hours (range 12-100 hours) and in $70 \%$ of the cases the sampling was done within 2 days from first injection. The patients were recruited from the obstetrical departments of Linköping University Hospital and County Hospital Ryhov in Jönköping. As controls, 20 women with normal pregnancy and 20 healthy non-pregnant women were included (Table 2). The normal pregnant women were included (gestational week 24-27) at their regular second trimester control at the antenatal clinic. Ten of the normal pregnant and ten of the 
non-pregnant women were also included in a previous paper (36). There was no significant difference across the three groups with regard to age, parity and body mass index, whereas the gestational age was significantly lower $(\mathrm{p}<0.001)$ in the normal pregnant compared with the preeclamptic women. Informed consent was obtained from all participants. The local ethics committee at Linköping University approved the study.

\section{Six-colour flow cytometry}

One million peripheral blood mononuclear cells (PBMC), prepared from EDTA blood as described previously (36), were incubated with fluorochrome-conjugated antibodies against human CD3 (APC-Cy7, clone SK7), CD4 (PerCP, clone SK3), CD25 (APC, clone 2A3), CD45RA (FITC, clone L48), CD45R0 (PE-Cy7, clone UCHL1), CD127 (PE, clone hIL-7R-M21) and CCR4 (PE, clone 1G1), all from BD Biosciences, San Jose/San Diego, CA USA. Intracellular staining was done for anti-human FOXP3 (PE or FITC, clone PCH101, eBioscience, San Diego, CA, USA) and CTLA-4 (PE, clone BNI3, BD Biosciences) after fixation/permeabilization as described before (31). Background fluorescence was assessed by antibodies against irrelevant protein (isotype controls). Absolute leukocyte (CD45), T lymphocyte (CD3) and T helper (CD4) cell counts in whole EDTA blood were determined by using bead-based TruCount tubes (BD Biosciences) as described by the manufacturer.

\section{Flow cytometric gating}

PBMC were collected using the FACSCanto II system (BD Biosciences) and analyzed with the Kaluza software (version 1.2, Beckman Coulter, Miami, USA). All gating analyses were performed in a blinded manner, i.e. the evaluator was unaware of the diagnosis. 
The lymphocyte gate was set according to characteristic forward and side scatter properties and cells were subsequently gated for co-expression of CD3 and CD4 (Fig.1a). Treg cells

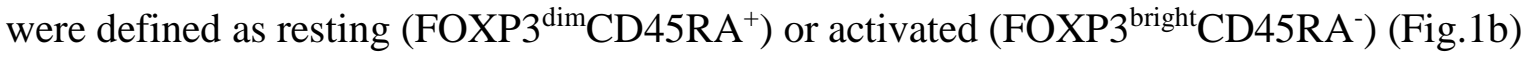
according to the gating strategy described by Miyara et al (38). A gate was also set for the non-suppressive $\mathrm{FOXP}^{+} \mathrm{T}$ helper cells $\left(\mathrm{FOXP} 3^{\mathrm{dim}} \mathrm{CD} 45 \mathrm{RA}^{-}\right)$. The FOXP3 $3^{\text {bright }}$ gate was set to include cells expressing the very highest levels of FOXP3, while FOXP3 ${ }^{\text {dim }}$ gated cells were slightly lower in FOXP3 expression but still positive. Owing to the reciprocal nature of $\mathrm{CD} 45 \mathrm{RA}^{+}$and $\mathrm{CD} 45 \mathrm{RO}^{-}$, we tested whether they could be used inter-changeably as markers of resting (or naïve) status of T cells. We found that Treg cells defined by either $\mathrm{CD}^{2} 5 \mathrm{RA}^{-}$or $\mathrm{CD} 45 \mathrm{RO}^{+}$were highly correlated in all comparisons (rho $\left.=0.99, \mathrm{p}<0.001\right)$. The definitions of CD45RA and CD45RO were determined by identifying the contours of positive populations (Fig. $1 \mathrm{~b}$-c). Our observation that resting and activated Treg cells can be defined also as FOXP $3{ }^{\text {dim }} \mathrm{CD} 45 \mathrm{RO}^{-}$and $\mathrm{FOXP} 3{ }^{\text {bright }} \mathrm{CD} 45 \mathrm{RO}^{+}$, respectively, made it feasible to evaluate CTLA-4 and CCR4 expression within these Treg subpopulations (Fig. 1d-e). To define the cut-off for positivity of CCR4 and CTLA-4, negative populations were used in combination with isotype controls.

For comparison with previous findings (36), gating of $\mathrm{CD} 4{ }^{\mathrm{dim}} \mathrm{CD} 25^{\text {bright }}$ cells was also performed (Fig. 1). The $\mathrm{CD} 4{ }^{\mathrm{dim}} \mathrm{CD} 25^{\text {bright }}$ gate was adjusted to contain cells expressing slightly lower levels of CD4 compared with conventional $\mathrm{CD} 4^{+}$cells, in combination with the highest levels of CD25. We previously showed this population to contain highly suppressive Treg cells avoiding activated non-suppressive cells (36). Reduced or absent expression of CD127, in combination with positivity for FOXP3 or CD25, defined the CD127 ${ }^{\text {low }}$ gate (Fig.1g) (37).

\section{Statistics}


Since the majority of the data sets followed a Gaussian distribution, data were analyzed using ANOVA followed by Student's unpaired t-test if the ANOVA indicated $p \leq 0.05$. For correlation analyses Pearson's correlation test was used. A significance level of $\mathrm{p} \leq$ 0.05 was used.

\section{RESULTS}

The total numbers of lymphocytes, $\mathrm{CD}^{+}$and $\mathrm{CD} 4^{+}$cells (expressed as cells/uL of whole blood) were similar in non-pregnant, normal pregnant and preeclamptic women $(\mathrm{p}=0.59$ 0.70, data not shown). Thus, Treg populations could safely be reported as the proportion of $\mathrm{CD} 4^{+}$cells (expressed as percentage of $\mathrm{CD} 3^{+} \mathrm{CD} 4^{+}$cells). Corticosteroid treatment neither affected the total number of lymphocytes nor the number of $\mathrm{CD}^{+}$or $\mathrm{CD} 4^{+}$cells $(\mathrm{p}=0.67-$ $0.84)$ when comparing corticosteroid treated $(n=10)$ and untreated $(n=8)$ women.

\section{Similar frequencies of resting and activated circulating Treg subpopulations in women with severe or early-onset preeclampsia and normal pregnancy}

The proportions of the resting and activated Treg subpopulations were similar in pregnant women with and without preeclampsia and in non-pregnant women, as was the frequency of the non-suppressive FOXP $3{ }^{\text {dim }}$ CD45RA- population (Fig.2 a-c). Also when adding the resting and activated Treg populations, as well as when defining Treg cells by CD127 ${ }^{\text {low }}$ combined with CD25 or FOXP3, there were no differences in between groups. When Treg

cells were defined as CD4 ${ }^{\mathrm{dim}} \mathrm{CD} 25^{\text {bright }}$ (Fig.1f) (36) pregnant women, both with preeclampsia and healthy pregnancy, showed lower proportions as compared with nonpregnant women (Fig.2d).

\section{Corticosteroid treatment affects the frequency of circulating Treg cells}


As can be seen in Figure 2 (unfilled versus filled circles in the preeclampsia group), the Treg populations seemed to be differently distributed in corticosteroid treated versus nontreated women. We therefore stratified the preeclampsia group according to status of corticosteroid treatment given prior to blood sampling (Fig.3). Thereby, among women with preeclampsia, corticosteroid treatment was associated with a reduced proportion of resting Treg cells (Fig.3a), whereas there were no significant differences with regard to activated Treg cells (Fig.3b) or the activated non-suppressive FOXP3 ${ }^{\mathrm{dim}} \mathrm{CD}^{2} 4 \mathrm{RA}^{-}$ population (Fig.3c).

However, in an attempt to relate the Treg cells to the effector CD4 cells, we found that the ratio (Fig.3d) between the sum of resting and activated Treg (FOXP3 ${ }^{\mathrm{dim}} \mathrm{CD} 45 \mathrm{RA}^{+}$and FOXP3 $3^{\text {high }} \mathrm{CD} 45 \mathrm{RA}^{-}$) and the activated non-suppressive FOXP $3{ }^{\mathrm{dim}} \mathrm{CD} 45 \mathrm{RA}^{-}$population, was significantly higher in non-corticosteroid treated preeclamptic women compared with normal pregnant women. This difference was also found in the entire group of preeclamptic women $(\mathrm{p}=0.01)$, while there was no significant increase in the corticosteroidtreated preeclamptic women compared with normal pregnant women. Nonpregnant women had a higher ratio than normal pregnant women (Fig. 3d).

Finally, the $\mathrm{CD} 4{ }^{\mathrm{dim}} \mathrm{CD} 25^{\text {bright }}$ Treg population was lower in the corticosteroid treated group, but not in the untreated group, as compared with non-pregnant women (Fig.3e).

\section{Severe or early-onset preeclampsia is associated with divergent CTLA-4 and CCR4 expression in circulating Treg subpopulations}

When looking at expression within Treg subpopulations, we found that the proportions of $\mathrm{CTLA}-4^{+}$and $\mathrm{CCR} 4^{+}$were higher both in resting and in activated Treg populations (Fig.4a-d) in untreated preeclamptic compared with normal pregnant women. In contrast, normal pregnancy was associated with lower proportions of CTLA- $4^{+}$(Fig.4b) and CCR $4^{+}$ 
cells (Fig.4d) within the activated Treg population as compared with non-pregnant women. Thus, differences in CTLA-4 and CCR4 expression within Treg populations were found in preeclamptic women. However, these differences were confined to the non-corticosteroidtreated group, again indicating an influence of corticosteroid treatment on the Treg phenotype.

\section{DISCUSSION}

In this study we used different up-to-date phenotyping strategies to assess Treg frequencies in early onset and severe preeclampsia. We found no major alterations in circulating Treg frequencies compared with healthy pregnant and non-pregnant women. However, by analyzing expression of functional and migratory markers (CTLA-4 and CCR4) within subpopulations we found alterations of Treg cells in preeclampsia. We also observed that corticosteroid treatment affected the Treg phenotype, thus important to consider when evaluating Treg cells in preeclampsia. Most previous studies on Treg cells in preeclampsia have reported decreased levels compared with normal pregnancy (30). Factors that may affect results and explain divergent findings include strategy and markers of Treg phenotyping, patient selection and influence of corticosteroid treatment.

Although there is still no perfect marker of Treg cells, there has been a gradual improvement in phenotyping strategies and markers in order both to define Treg cell subpopulations and to exclude non-suppressive $\mathrm{CD}^{+}{ }^{+}$cells that express FOXP3 and CD25 after activation. A major breakthrough was the report by Miyara et al., demonstrating that by combining FOXP3 with CD45RA, Treg cells were classified as either resting $\left(\mathrm{FOXP}^{\mathrm{dim}} \mathrm{CD} 45 \mathrm{RA}^{+}\right)$or activated $\left(\mathrm{FOXP} 3{ }^{\text {high }} \mathrm{CD} 45 \mathrm{RA}^{-}\right)$, while at the same time FOXP3 ${ }^{\mathrm{dim}} \mathrm{CD} 45 \mathrm{RA}^{-}$cells were classified as activated non-suppressive T cells ("false positive" FOXP3 expression) and therefore correctly excluded from the Treg cell 
enumeration $(30,38,42)$. When using this strategy we found that neither the total Treg frequency nor the balance between resting and activated Treg cells was altered in preeclampsia versus normal pregnancy. Furthermore, also when using other strategies that avoid activated non-suppressive FOXP3 $3^{+}$T cells $\left(\mathrm{CD} 127^{\text {low }}(37)\right.$ and $\mathrm{CD} 4^{\mathrm{dim}} \mathrm{CD} 25^{\text {bright }}$ (36)) we found no differences between preeclampsia and normal pregnancy. Our findings do not support the majority of previous studies that in general showed lower frequencies of Treg cells in blood of preeclamptic as opposed to healthy pregnant women (19, 24, 43-49), although some previous studies did not show a difference between these groups $(32,33$, 44). In a more recent study, by using an updated phenotyping strategy, Steinborn et al. did not find any differences with regard to the whole Treg cell population, while alterations in the preeclampsia group were found in Treg subpopulations (31), in line with our findings (see below). Taken together, the phenotyping strategy has a major impact on Treg cell frequencies and must be taken into account when evaluating previous studies that may have included activated non-suppressive $\mathrm{FOXP}^{+}$or $\mathrm{CD}^{2} 5^{+}$cells.

In addition to the phenotyping strategy, the selection of material can affect findings. Although previous studies have enrolled patients with mainly moderate to severe preeclampsia, none has focused on early-onset disease and in several studies findings were not related to gestational age. Hence, some of the Treg disturbances reported previously may have been confined to the group of women presenting with late-onset preeclampsia, possibly having had a subclinical disease for a long time and findings could therefore reflect the effect of, rather than the cause of the disease. We focused our attention on women with severe or early-onset preeclampsia, hypothesizing that this would provide us with a homogenous group of diseased women presenting with a more distinct placental disease $(34,50)$. This is also the patient group suffering the most severe consequences of 
their disease. However, our findings do not support a numerical defect in Treg cells in early-onset preeclampsia.

Due to the early onset of the disease and the high risk of premature birth, ten of the preeclamptic women in our study received the potent glucocorticoid betamethasone, which was given in almost all cases in close proximity to blood sampling. This treatment is normally started directly at admission of a patient with early onset preeclampsia. The women in the preeclampsia group were recruited at the County Hospital Ryhov in Jönköping and the University Hospital in Linköping, but several women were transferred from smaller hospitals and corticosteroid treatment had already been started at admission. Importantly, we found that the corticosteroid-treated group showed significantly decreased frequencies of resting Treg cells, and corticosteroid treatment also affected the composition of Treg subpopulations. In humans, dexamethasone has been shown to promote Treg cells $(35,51,52)$, while BALB/c mice treated with dexamethasone showed enhanced $\mathrm{CD} 4^{+} \mathrm{CD} 25^{+}$but suppressed $\mathrm{CD} 4^{+} \mathrm{FOXP} 3^{+}$Treg cell numbers (53). Further, Treg cell numbers were unaffected by hydrocortisone in a murine model of autoimmune disease (54). Obviously, the glucocorticoid effects on Treg cells are complex and related to the dose and duration of the treatment. Hence, using samples from non-glucocorticoid-treated women is desirable. In previous studies the use of corticosteroid treatment was in general not reported, and its effects on Treg cells has not been previously evaluated in preeclamptic women.

The aberrant findings in preeclamptic compared with normal pregnant women in this study were related to function (CTLA-4) and chemotaxis (CCR4) of Treg cells. CTLA-4 is a key element in the suppressive effect of Treg cells (55), while CCR4 mediates migration of $\mathrm{CCR}^{+}{ }^{+} \mathrm{T}$ cells, such as $\mathrm{T}_{\mathrm{H}} 2$-like cells and subsets of activated Treg cells, to the fetalmaternal interface, which is rich for the CCR4 ligand CCL17 $(29,56)$. In normal 
pregnancy compared with the non-pregnant state, we found a reduced frequency in blood of both CTLA $-4^{+}$and $\mathrm{CCR} 4^{+}$cells within the activated Treg population $\left(\mathrm{FOXP} 3{ }^{\text {high }} \mathrm{CD} 45 \mathrm{RO}^{+}\right)$. This reduction in blood is in line with an accumulation of suppressive Treg cells in the decidua, as reported previously (23). Consequently, the presently noted increase in preeclampsia of the $\mathrm{CTLA}^{+}$and $\mathrm{CCR} 4^{+}$fractions of Treg cells could reflect a failure to accumulate Treg cells in the decidua, hence leading to a lack of anti-inflammatory regulation at the fetal-maternal interface. Indeed, a lowered frequency of Treg cells in the decidua has been found in preeclampsia $(46,57)$. In an attempt to relate the Treg cell frequency to effector CD4 cells, we used the resting plus the activated Treg cells as reliable measures of true Treg cells, and the activated non-suppressive CD4 population as an established activated population (38). When making a ratio between resting and activated Treg cells divided by the effector $\mathrm{T}$ cells, we found a higher ratio in non-corticosteroid treated women compared with both normal pregnant and corticosteroid treated women. This finding is in line with a possible migratory defect of Treg cells in preeclampsia, i.e. that Treg cells do not properly reach their destination in the uterus, while the effector cells are recruited to the uterus, hence occurring at lower level in the circulation relative to the Treg cells. Of note, the differences in the ratio must be interpreted with great caution since there were no significant differences when evaluating the fractions one by one.

A limitation of our study is that we have only studied Treg cell frequency in peripheral blood and not locally in decidua. A strength of the study is that only women with earlyonset or severe preeclampsia with clear signs of placental pathology were included, and so is our stratifying for corticosteroid treatment as well as the use of an up-dated phenotyping panel assessing Treg subpopulations and excluding non-suppressive activated FOXP3expressing cells. The sample size is not huge but similar to most previous studies that have 
noted differences in Treg cell frequencies. When stratifying for corticosteroid treatment, the subgroups are rather small and our findings need to be confirmed. However, significant differences were still noted and they are sufficient to draw the attention to the issue of corticosteroid treatment in future studies.

There was also a difference of approximately four weeks in mean gestational age between the group of preeclamptic women and the normal pregnant women. Steinborn et al found that the suppressive action of Treg cells was quite stable after 20 weeks of pregnancy until time close to labor (31). None of the women in the study were close to spontaneous labor in the study and we therefore believe that this difference has not affected the results in any significant way.

In conclusion, although we found no major alterations in circulating Treg numbers, increased fractions of CTLA-4 and CCR $4^{+}$cells within Treg subpopulations are in line with a migratory defect of Treg cells in preeclampsia, potentially associated with a reduced number of suppressive Treg cells at the fetal maternal interface. Since corticosteroid treatment seems to affect the distribution of Treg subpopulations, this variable should be accounted for in studies of Treg cells in preeclampsia. 


\section{REFERENCES}

1. Duley L. The global impact of pre-eclampsia and eclampsia. Semin Perinatol. 2009;33:130-7.

2. Redman CW, Sargent IL. Immunology of pre-eclampsia. Am J Reprod Immunol. 2010;63:534-43.

3. Matthiesen L, Berg G, Ernerudh J, Ekerfelt C, Jonsson Y, Sharma S. Immunology of preeclampsia. Chem Immunol Allergy. 2005;89:49-61.

4. Laresgoiti-Servitje E. A leading role for the immune system in the pathophysiology of preeclampsia. J Leukoc Biol. 2013;94:247-57.

5. Catarino C, Santos-Silva A, Belo L, Rocha-Pereira P, Rocha S, Patricio B, et al. Inflammatory disturbances in preeclampsia: relationship between maternal and umbilical cord blood. J Pregnancy.2012:684384.

6. Boij R, Svensson J, Nilsson-Ekdahl K, Sandholm K, Lindahl TL, Palonek E, et al. Biomarkers of coagulation, inflammation, and angiogenesis are independently associated with preeclampsia. Am J Reprod Immunol. 2012;68:258-70.

7. Jonsson Y, Ruber M, Matthiesen L, Berg G, Nieminen K, Sharma S, et al. Cytokine mapping of sera from women with preeclampsia and normal pregnancies. J Reprod Immunol. 2006;70:83-91.

8. Darmochwal-Kolarz D, Leszczynska-Gorzelak B, Rolinski J, Oleszczuk J. T helper 1and T helper 2-type cytokine imbalance in pregnant women with pre-eclampsia. Eur J Obstet Gynecol Reprod Biol. 1999;86:165-70.

9. Matthiesen L, Berg G, Ernerudh J, Skogh T. Lymphocyte subsets and autoantibodies in pregnancies complicated by placental disorders. Am J Reprod Immunol. $1995 ; 33: 31-9$. 
10. Chaiworapongsa T, Gervasi MT, Refuerzo J, Espinoza J, Yoshimatsu J, Berman S, et al. Maternal lymphocyte subpopulations (CD45RA+ and CD45RO+) in preeclampsia. Am J Obstet Gynecol. 2002;187:889-93.

11. Saito S, Sakai M, Sasaki Y, Tanebe K, Tsuda H, Michimata T. Quantitative analysis of peripheral blood Th0, Th1, Th2 and the Th1:Th2 cell ratio during normal human pregnancy and preeclampsia. Clin Exp Immunol. 1999;117:550-5.

12. Szarka A, Rigo J, Jr., Lazar L, Beko G, Molvarec A. Circulating cytokines, chemokines and adhesion molecules in normal pregnancy and preeclampsia determined by multiplex suspension array. BMC Immunol. 2010;11:59..

13. Sakaguchi S, Wing K, Onishi Y, Prieto-Martin P, Yamaguchi T. Regulatory T cells: how do they suppress immune responses? International immunology. 2009;21:110511.

14. Baecher-Allan C, Brown JA, Freeman GJ, Hafler DA. CD4+CD25high regulatory cells in human peripheral blood. J Immunol. 2001 1;167:1245-53.

15. Saito S, Sasaki Y, Sakai M. CD4(+)CD25high regulatory T cells in human pregnancy. J Reprod Immunol. 2005;65:111-20.

16. Vignali DA, Collison LW, Workman CJ. How regulatory T cells work. Nat Rev Immunol. 2008;8:523-32.

17. Somerset DA, Zheng Y, Kilby MD, Sansom DM, Drayson MT. Normal human pregnancy is associated with an elevation in the immune suppressive CD25+CD4+ regulatory T-cell subset. Immunology. 2004;112:38-43.

18. Sasaki Y, Sakai M, Miyazaki S, Higuma S, Shiozaki A, Saito S. Decidual and peripheral blood CD4+CD25+ regulatory T cells in early pregnancy subjects and spontaneous abortion cases. Mol Hum Reprod. 2004;10:347-53. 
19. Toldi G, Saito S, Shima T, Halmos A, Veresh Z, Vasarhelyi B, et al. The frequency of peripheral blood CD4+ CD25high FoxP3+ and CD4+ CD25- FoxP3+ regulatory T cells in normal pregnancy and pre-eclampsia. Am J Reprod Immunol. 2012;68(2):175-80. 20. Heikkinen J, Mottonen M, Alanen A, Lassila O. Phenotypic characterization of regulatory T cells in the human decidua. Clin Exp Immunol. 2004;136:373-8.

21. Kisielewicz A, Schaier M, Schmitt E, Hug F, Haensch GM, Meuer S, et al. A distinct subset of HLA-DR+-regulatory T cells is involved in the induction of preterm labor during pregnancy and in the induction of organ rejection after transplantation. Clin Immunol. 2010;137:209-20.

22. Tilburgs T, Roelen DL, van der Mast BJ, van Schip JJ, Kleijburg C, de Groot-Swings GM, et al. Differential distribution of CD4(+)CD25(bright) and CD8(+)CD28(-) T-cells in decidua and maternal blood during human pregnancy. Placenta. 2006;27 Suppl A:S47-53.

23. Tilburgs T, Roelen DL, van der Mast BJ, de Groot-Swings GM, Kleijburg C, Scherjon SA, et al. Evidence for a selective migration of fetus-specific CD4+CD25bright regulatory T cells from the peripheral blood to the decidua in human pregnancy. J Immunol. 2008; 15;180:5737-45..

24. Steinborn A, Haensch GM, Mahnke K, Schmitt E, Toermer A, Meuer S, et al. Distinct subsets of regulatory T cells during pregnancy: is the imbalance of these subsets involved in the pathogenesis of preeclampsia? Clin Immunol. 2008;129:401-12. 25. Wegienka G, Havstad S, Bobbitt KR, Woodcroft KJ, Zoratti EM, Ownby DR, et al. Within-woman change in regulatory $\mathrm{T}$ cells from pregnancy to the postpartum period. J Reprod Immunol. 2010;88:58-65. 
26. Ernerudh J, Berg G, Mjosberg J. Regulatory T helper cells in pregnancy and their roles in systemic versus local immune tolerance. Am J Reprod Immunol. 2011;66 Suppl 1:31-43.

27. Dimova T, Nagaeva O, Stenqvist AC, Hedlund M, Kjellberg L, Strand M, et al. Maternal Foxp3 expressing CD4+ CD25+ and CD4+ CD25- regulatory T-cell populations are enriched in human early normal pregnancy decidua: a phenotypic study of paired decidual and peripheral blood samples. Am J Reprod Immunol. 2011;66 Suppl 1:44-56.

28. Mjosberg J, Berg G, Jenmalm MC, Ernerudh J. FOXP3+ regulatory T cells and T helper 1 , T helper 2 , and T helper 17 cells in human early pregnancy decidua. Biol Reprod. 2010;82:698-705.

29. Tsuda H, Michimata T, Hayakawa S, Tanebe K, Sakai M, Fujimura M, et al. A Th2 chemokine, TARC, produced by trophoblasts and endometrial gland cells, regulates the infiltration of CCR4+ T lymphocytes into human decidua at early pregnancy. Am J Reprod Immunol. 2002;48:1-8.

30. Jiang TT, Chaturvedi V, Ertelt JM, Kinder JM, Clark DR, Valent AM, et al. Regulatory T cells: new keys for further unlocking the enigma of fetal tolerance and pregnancy complications. J Immunol. 2014 1;192:4949-56.

31. Steinborn A, Schmitt E, Kisielewicz A, Rechenberg S, Seissler N, Mahnke K, et al. Pregnancy-associated diseases are characterized by the composition of the systemic regulatory T cell (Treg) pool with distinct subsets of Tregs. Clin Exp Immunol. 2012;167:84-98.

32. Hu D, Chen Y, Zhang W, Wang H, Wang Z, Dong M. Alteration of peripheral CD4+CD25+ regulatory T lymphocytes in pregnancy and pre-eclampsia. Acta Obstet Gynecol Scand. 2008;87:190-4. 
33. Paeschke S, Chen F, Horn N, Fotopoulou C, Zambon-Bertoja A, Sollwedel A, et al. Pre-eclampsia is not associated with changes in the levels of regulatory $\mathrm{T}$ cells in peripheral blood. Am J Reprod Immunol. 2005;54:384-9.

34. Ilekis JV, Reddy UM, Roberts JM. Preeclampsia--a pressing problem: an executive summary of a National Institute of Child Health and Human Development workshop. Reprod Sci. 2007;14:508-23.

35. Dimeloe S, Nanzer A, Ryanna K, Hawrylowicz C. Regulatory T cells, inflammation and the allergic response-The role of glucocorticoids and Vitamin D. J Steroid Biochem Mol Biol. 2010 31;120:86-95.

36. Mjosberg J, Svensson J, Johansson E, Hellstrom L, Casas R, Jenmalm MC, et al. Systemic reduction of functionally suppressive CD4dimCD25highFoxp3+ Tregs in human second trimester pregnancy is induced by progesterone and 17beta-estradiol. J Immunol. 2009 1;183:759-69.

37. Liu W, Putnam AL, Xu-Yu Z, Szot GL, Lee MR, Zhu S, et al. CD127 expression inversely correlates with FoxP3 and suppressive function of human CD4+ T reg cells. J Exp Med. 2006 10;203:1701-11.

38. Miyara M, Yoshioka Y, Kitoh A, Shima T, Wing K, Niwa A, et al. Functional delineation and differentiation dynamics of human CD4+ T cells expressing the FoxP3 transcription factor. Immunity. 2009 19;30:899-911.

39. American College of Obstetricians and gynecologists ibI. Hypertension, Pregnancy-Induced-Practice Guideline. 2013.

40. Raymond D, Peterson E. A critical review of early-onset and late-onset preeclampsia. Obstet Gynecol Surv. 2011;66:497-506. 
41. Witlin AG, Saade GR, Mattar F, Sibai BM. Predictors of neonatal outcome in women with severe preeclampsia or eclampsia between 24 and 33 weeks' gestation. Am J Obstet Gynecol. 2000;182:607-11.

42. Miyara M, Gorochov G, Ehrenstein M, Musset L, Sakaguchi S, Amoura Z. Human FoxP3+ regulatory T cells in systemic autoimmune diseases. Autoimmun Rev. 2011;10:744-55.

43. Darmochwal-Kolarz D, Kludka-Sternik M, Tabarkiewicz J, Kolarz B, Rolinski J, Leszczynska-Gorzelak B, et al. The predominance of Th17 lymphocytes and decreased number and function of Treg cells in preeclampsia. J Reprod Immunol. 2012;93:7581.

44. Prins JR, Boelens HM, Heimweg J, Van der Heide S, Dubois AE, Van Oosterhout AJ, et al. Preeclampsia is associated with lower percentages of regulatory T cells in maternal blood. Hypertens Pregnancy. 2009;28:300-11.

45. Toldi G, Svec P, Vasarhelyi B, Meszaros G, Rigo J, Tulassay T, et al. Decreased number of FoxP3+ regulatory T cells in preeclampsia. Acta Obstet Gynecol Scand. 2008;87:1229-33.

46. Sasaki Y, Darmochwal-Kolarz D, Suzuki D, Sakai M, Ito M, Shima T, et al. Proportion of peripheral blood and decidual CD4(+) CD25(bright) regulatory T cells in pre-eclampsia. Clin Exp Immunol. 2007;149:139-45.

47. Santner-Nanan B, Peek MJ, Khanam R, Richarts L, Zhu E, Fazekas de St Groth B, et al. Systemic increase in the ratio between Foxp3+ and IL-17-producing CD4+ T cells in healthy pregnancy but not in preeclampsia. J Immunol. 2009 1;183:7023-30. 48. Hsu P, Santner-Nanan B, Dahlstrom JE, Fadia M, Chandra A, Peek M, et al. Altered decidual DC-SIGN+ antigen-presenting cells and impaired regulatory T-cell induction in preeclampsia. Am J Pathol. 2012;181:2149-60. 
49. Darmochwal-Kolarz D, Kludka-Sternik M, Tabarkiewicz J, Kolarz B, Rolinski J, Leszczynska-Gorzelak B, et al. The predominance of Th17 lymphocytes and decreased number and function of Treg cells in preeclampsia. J Reprod Immunol. 2012 ;93:7581.

50. Vatten LJ, Skjaerven R. Is pre-eclampsia more than one disease? BJOG. 2004 ;111:298-302.

51. Karagiannidis C, Akdis M, Holopainen P, Woolley NJ, Hense G, Ruckert B, et al. Glucocorticoids upregulate FOXP3 expression and regulatory T cells in asthma. J Allergy Clin Immunol. 2004;114:1425-33.

52. Navarro J, Aristimuno C, Sanchez-Ramon S, Vigil D, Martinez-Gines ML, Fernandez-Cruz E, et al. Circulating dendritic cells subsets and regulatory T-cells at multiple sclerosis relapse: differential short-term changes on corticosteroids therapy. J Neuroimmunol. 2006;176:153-61.

53. Chen X, Oppenheim JJ, Winkler-Pickett RT, Ortaldo JR, Howard OM. Glucocorticoid amplifies IL-2-dependent expansion of functional FoxP3(+)CD4(+)CD25(+) T regulatory cells in vivo and enhances their capacity to suppress EAE. Eur J Immunol. 2006;36:2139-49.

54. Moraes-Fontes MF, Rebelo M, Caramalho I, Zelenay S, Bergman ML, Coutinho A, et al. Steroid treatments in mice do not alter the number and function of regulatory $\mathrm{T}$ cells, but amplify cyclophosphamide-induced autoimmune disease. J Autoimmun. 2009;33:109-20.

55. Wing K, Yamaguchi T, Sakaguchi S. Cell-autonomous and -non-autonomous roles of CTLA-4 in immune regulation. Trends Immunol. 2011;32:428-33.

56. Lim HW, Broxmeyer HE, Kim CH. Regulation of trafficking receptor expression in human forkhead box P3+ regulatory T cells. J Immunol. 2006 15;177:840-51. 
57. Quinn KH, Lacoursiere DY, Cui L, Bui J, Parast MM. The unique pathophysiology of early-onset severe preeclampsia: role of decidual T regulatory cells. J Reprod Immunol. 2011;91:76-82. 
Acknowledgements

We would like to thank the women who participated in the study and midwives at labor wards in County Hospital Ryhov in Jönköping and University Hospital in Linköping for collection of samples.

This study was supported financially by FORSS (Medical Research Council of Southeast Sweden) and Futurum, - academy for Health and Care Jönköping County Council, Sweden

The authors declare no conflicts of interest 


\section{FIGURES}
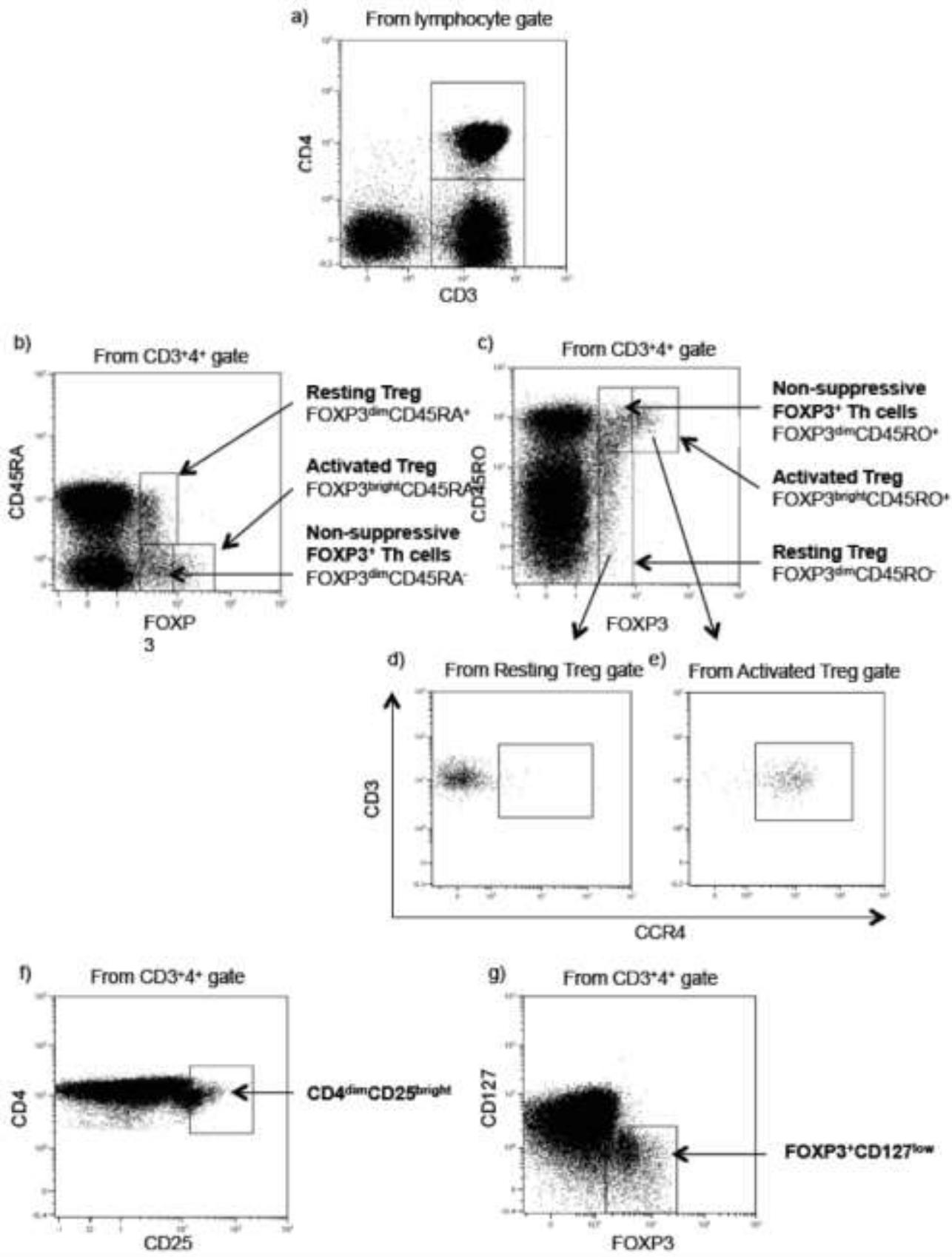

Figure 1.

Gating strategy for regulatory (Treg) cells. (a) Representative dot plot of $\mathrm{CD} 3{ }^{+} \mathrm{CD} 4^{+}$cells in lymphocytes. (b) Subpopulations of $\mathrm{CD}^{+} \mathrm{CD}^{+}$cells defined by expression of CD45RA and FOXP3: resting Treg cells (FOXP $3{ }^{\text {dim }}{ }$ D $\left.45 \mathrm{RA}^{+}\right)$, activated Treg cells $\left(\mathrm{FOXP} 3{ }^{\text {bright }} \mathrm{CD} 45 \mathrm{RA}^{-}\right)$ and non-suppressive Th cells (FOXP $\left.3{ }^{\mathrm{dim}} \mathrm{CD} 45 \mathrm{RA}^{-}\right)$. (c) Corresponding resting and activated subpopulations, defined by CD45RO and FOXP3. (d) Expression of CCR4 in resting and (e) activated Tregs. (f) The CD $4{ }^{\mathrm{dim}} \mathrm{CD} 25^{\text {bright }}$ gate was set to contain cells expressing high levels of CD25 and slightly lower levels of CD4 than the total CD4 ${ }^{+}$population. (g) Low or absent expression of CD127 in combination with FOXP3 in $\mathrm{CD}^{+}{ }^{+}$cells (FOXP3 $3^{+} \mathrm{CD} 127^{\text {low }}$ ). 
Figure 2
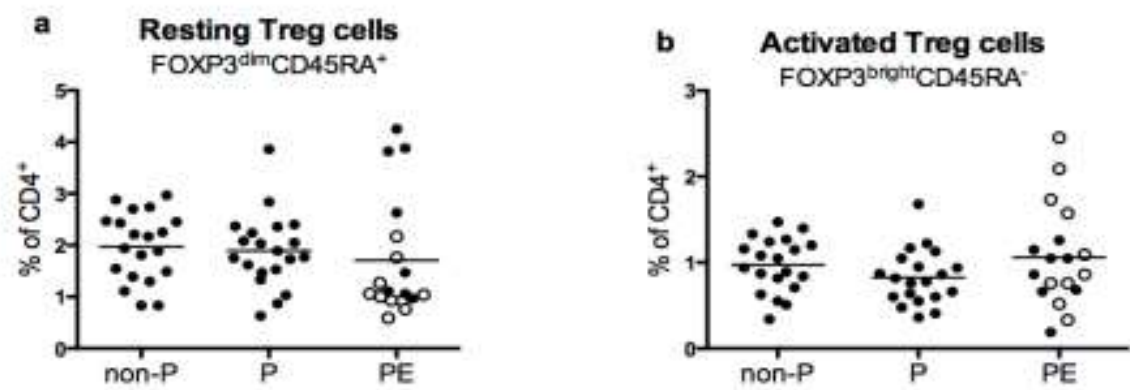

c Non-suppressive FoxP3+Th cells
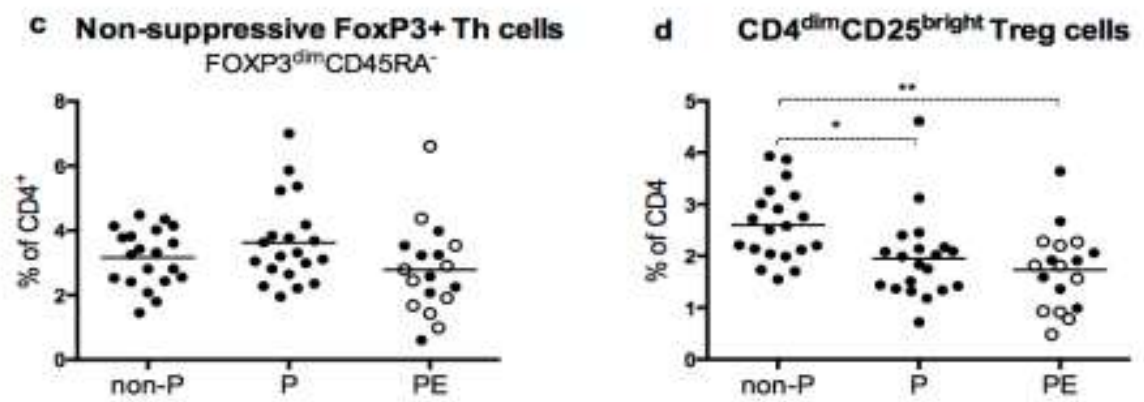

Figure 2.

Proportions (\%) of Treg subpopulations in non-pregnant (non-P; $n=20)$, normal pregnant (P; $\mathrm{n}=20$ ) and preeclamptic (PE; $\mathrm{n}=18$ ) women: (a) resting Treg cells (FOXP3 $\left.{ }^{\mathrm{dim}} \mathrm{CD} 45 \mathrm{RA}\right)$; (b) activated Treg cells (FOXP $3{ }^{\text {high }} \mathrm{CD}^{2} 5 \mathrm{RA}^{-}$); (c) non-suppressive $\mathrm{FOXP} 3^{+}$Th cells (FOXP $3{ }^{\text {dim }}$ CD45RA ${ }^{-}$; (d) Treg cells defined as CD4 ${ }^{\text {dim }}$ CD25 ${ }^{\text {bright }}$ cells. Lines indicate mean values. Empty circles indicate corticosteroid treated preeclamptic women. $* \mathrm{p}<0.05 ; * * \mathrm{p}<0.01$ by Student's unpaired t-test if the ANOVA indicated $\mathrm{p} \leq 0.05$ 
Figure 3

a

Resting Treg cells

FOXP3 dimCD45RA'

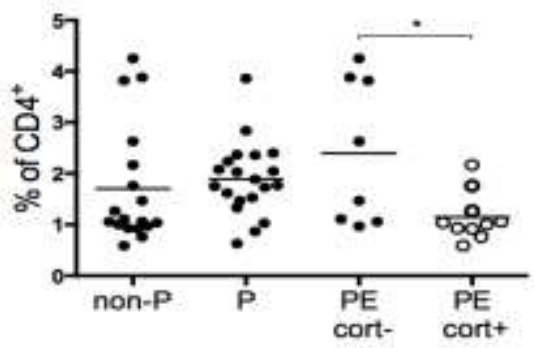

Non supressive FOXP3* Th cells

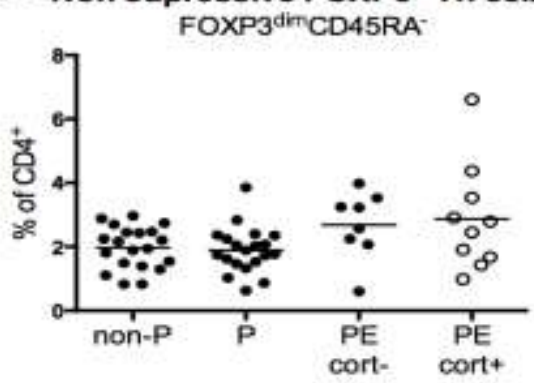

b Activated Treg cells

FOXP3 ${ }^{\text {bight }}$ CD45RA

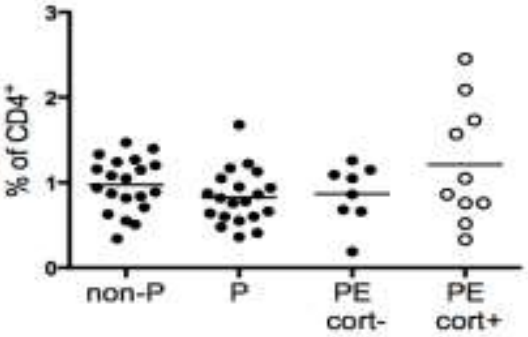

Resting+Activated Treg/ Non-suppressive FOXP3 ${ }^{+} \mathrm{T}$ cells

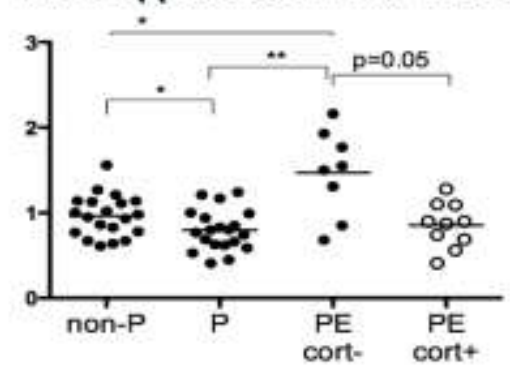

e CD4 $4^{\text {dim }}$ CD25 $5^{\text {bright }}$ Treg cells

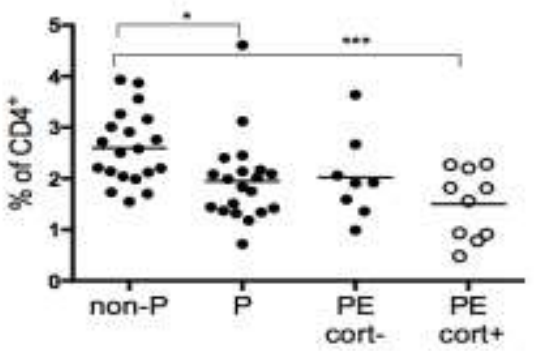

Figure 3.

Proportions (\%) of Treg subpopulations in non-pregnant (non-P; $\mathrm{n}=20)$, normal pregnant (P; $\mathrm{n}=20$ ), non-corticosteroid treated preeclamptic (PEcort-; $\mathrm{n}=8$ ) and corticosteroid treated (PEcort+; $\mathrm{n}=10$ ) women: (a) resting Treg cells (FOXP3 $\left.{ }^{\mathrm{dim}} \mathrm{CD} 45 \mathrm{RA}\right)$; (b) activated Treg cells (FOXP $3{ }^{\text {high }} \mathrm{CD}^{4} 4 \mathrm{RA}^{-}$); (c) non-suppressive FOXP3 ${ }^{+} \mathrm{T}$ cells $\left(\mathrm{FOXP} 3{ }^{\mathrm{dim}} \mathrm{CD} 45 \mathrm{RA}^{-}\right.$); (d) ratio between the sum of resting and activated Treg defined as in $a-b$, divided by the proportion of non-suppressive FOXP3 ${ }^{+}$T cells (e) Treg cells defined as CD $4^{\text {dim }} \mathrm{CD} 25^{\text {bright }}$ cells. Lines indicate mean values.

$* \mathrm{p}<0.05 ; * * \mathrm{p}<0.01$ by Student's unpaired t-test if the ANOVA indicated $\mathrm{p} \leq 0.05$ 

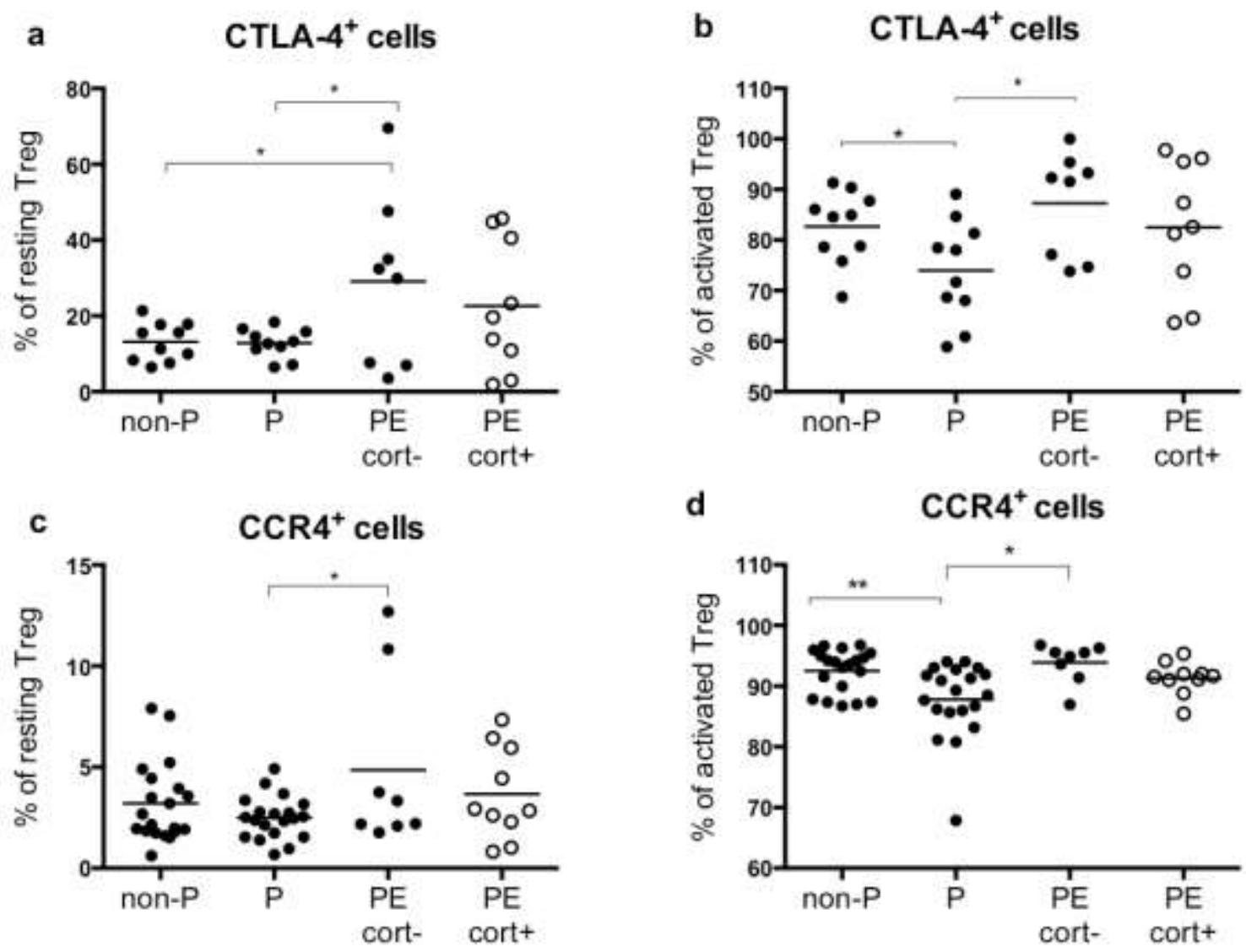

\section{Figure 4.}

Proportions (\%) of CTLA $-4^{+}$and CCR4 ${ }^{+}$cells within (a, c) resting $\left(\mathrm{FOXP} 3{ }^{\mathrm{dim}} \mathrm{CD}^{2} 5 \mathrm{RO}^{-}\right)$and (b, d) activated (FOXP3 ${ }^{\text {bright }} \mathrm{CD}^{4} \mathrm{RO}^{+}$) Treg subpopulations in non-pregnant (non-P; $\mathrm{n}=20$ ), normal pregnant $(\mathrm{P} ; \mathrm{n}=20)$, non-corticosteroid treated preeclamptic (PEcort-; $\mathrm{n}=8)$ and corticosteroid treated (PEcort+; $\mathrm{n}=10$ ) women. Lines indicate mean values.

$* \mathrm{p}<0.05 ; * *^{*}<0.01$ by Student's unpaired t-test if the ANOVA indicated $\mathrm{p} \leq 0.05$ 


\section{TABLES}

Table I. Clinical data of the preeclamptic women included in the study

\begin{tabular}{|c|c|c|c|c|c|c|c|}
\hline & Age & $\mathrm{BP} *$ & Urine & $\begin{array}{l}\text { Onset } \\
\text { (GW) }\end{array}$ & $\begin{array}{l}\text { FW } \\
\text { deviation } \\
\%\end{array}$ & $\begin{array}{l}\text { Cortico- } \\
\text { steroid } \\
\text { treatment }\end{array}$ & Complications \\
\hline 1 & 27 & $160 / 105$ & $1+$ & $29+0$ & -28.1 & yes & \\
\hline 2 & 26 & $170 / 125$ & $3+$ & $28+0$ & -33.3 & yes & \\
\hline 3 & 28 & $180 / 105$ & $2+$ & $30+6$ & -38.0 & yes & abrubtio placentae \\
\hline 4 & 36 & $170 / 120$ & $3+$ & $31+2$ & -19.4 & yes & \\
\hline 5 & 34 & $200 / 120$ & $3+$ & $33+4$ & -26.4 & no & \\
\hline 6 & 31 & $185 / 115$ & $3+$ & $26+3$ & -28.3 & no & \\
\hline 7 & 17 & $190 / 120$ & $3+$ & $23+0$ & -13.8 & no & \\
\hline 8 & 21 & $180 / 110$ & $3+$ & $27+0$ & -27.4 & yes & eclampsia \\
\hline 9 & 46 & $195 / 115$ & $3+$ & $31+3$ & -31.7 & no & oliguria \\
\hline 10 & 35 & $170 / 105$ & $3+$ & $30+0$ & -6.0 & yes & HELLP \\
\hline 11 & 27 & $180 / 110$ & $3+$ & $27+0$ & -6.7 & yes & \\
\hline 12 & 24 & $200 / 120$ & $3+$ & $30+0$ & -32.9 & yes & \\
\hline 13 & 38 & $220 / 120$ & $3+$ & $29+4$ & -33.0 & yes & \\
\hline 14 & 31 & $160 / 90$ & $3+$ & $30+0$ & -34.8 & no & \\
\hline 15 & 39 & $180 / 100$ & $3+$ & $35+0$ & -20.0 & no & \\
\hline 16 & 31 & $170 / 100$ & $3+$ & $30+1$ & -24.8 & no & \\
\hline 17 & 38 & $140 / 90$ & $3+$ & $34+0$ & -15.3 & no & \\
\hline 18 & 27 & $140 / 95$ & $1+$ & $29+4$ & -32.7 & yes & thrombocytopenia \\
\hline
\end{tabular}

*BP, highest blood pressure during admission $\mathrm{GW}=$ Gestational Weeks; FW=Fetal Weight

HELLP=Hemolysis, Elevated Liver enzymes and Low Platelet Count 
Table II. Demographic and clinical data, given as median (and range within brackets) or as categorical data.

\begin{tabular}{|llll|}
\hline Subject characteristics & $\begin{array}{l}\text { Preeclamptic } \\
\text { women } \\
(\mathbf{n = 1 8})\end{array}$ & $\begin{array}{l}\text { Healthy pregnant } \\
\text { women } \\
(\mathbf{n}=\mathbf{2 0})\end{array}$ & $\begin{array}{l}\text { Non-pregnant } \\
\text { women } \\
(\mathbf{n = 2 0})\end{array}$ \\
\hline Age at inclusion & $29(17-46)$ & $28(19-38)$ & $27(20-36)$ \\
\hline Blood pressure & $\begin{array}{l}177 / 108 \\
(140 / 90-220 / 120)\end{array}$ & $\begin{array}{l}115 / 70 \\
(110 / 60-130 / 80)\end{array}$ & no information \\
\hline $\begin{array}{l}\text { Proteinuria (dipstick } \\
\text { grading) }\end{array}$ & $\begin{array}{l}3+ \\
(1+-3+)\end{array}$ & no proteinuria & no information \\
\hline $\begin{array}{l}\text { Gestational week at } \\
\text { inclusion (weeks) }\end{array}$ & $29(23-35)^{* *}$ & $25(24-27)$ & NA \\
\hline Partus (weeks) & $30(26-37)$ & $41(35-42)$ & NA \\
\hline Previous pregnancies (n) & $2(1-5)^{*}$ & $0(0-2)$ & $0(0-2)$ \\
\hline Previous births (n) & $0(0-2)$ & $0(0-1)$ & $0(0-2)$ \\
\hline BMI & $27(21-35)$ & $23(17-31)$ & no information \\
\hline
\end{tabular}

No significant differences for age at inclusion, parity or BMI.

*p $=0.029 * * p<0.001 \quad \mathrm{NA}$; not applicable 